\title{
Falar, Cantar, Gritar: o controle da voz feminina no cinema americano
}

\section{Speaking, Singing, Screaming: controlling the female voice in american cinema}

https://doi.org/10.34112/2317-0972a2017V35n70p67-83

\section{Liz Greene ${ }^{1}$}

RESUMO: Os pesquisadores dos estudos fílmicos feministas vêm argumentando, há muito tempo, que existe um preconceito visual na maneira como o corpo feminino é representado nas telas. Este artigo ${ }^{2}$ explora o prolongamento desse preconceito ao incluir o som: como o som é utilizado para representar as mulheres no cinema americano. Explora-se aqui a representação sonora em alguns filmes-chave, incluindo Dançando na Chuva (Singin'in the Rain), Cidade dos Sonhos (Mulholand Drive), Veludo Azul (Blue Velvet) e Cidadão Kane (Citizen Kane).

Palavras-chave: Som; voz feminina; canto; cinema americano.

AвSTRACT: Feminist film scholars have long argued that there is a visual bias as to how the female body is represented on screen. This article explores the extension of this bias to include sound: how sound is used to represent women in American cinema. It explores

1. Liverpool John Moores University, Liverpool, Inglaterra.

2. O texto foi publicado originalmente no The Soundtrack Journal (vol. 2, 2009), que permitiu sua republicação em português. Tradução de Marcus Novaes. GREENE, L. Speaking, Singing, Screaming: Controlling the Female Voice in American Cinema. The Soundtrack, 2, 1, p. 63-76, 2009. (N. T.: Devido a algumas referências da autora a termos mais técnicos dos estudos fílmicos e sonoros, buscamos esclarecê-los através da inserção de notas, a fim de possibilitar uma maior compreensão e aproximação com o texto. Sempre que possível, utilizamos as traduções para o português dos livros citados.) 
Falar, Cantar, Gritar: o controle da voz feminina no cinema americano

sonic representation in several key films including Singin' in the Rain, Mulholland Drive, Blue Velvet and Citizen Kane.

KEYWORDS: Sound; female voice; singing; american movies.

INTRODUÇÃO

Em 1988, Kaja Silverman afirmou que a trilha sonora também é construída a partir de questões de gênero:

É curioso [...] que a crítica feminista do cinema clássico tenha focado primeiramente a trilha imagética e a construção da mulher como objeto do olhar masculino [...]. De alguma forma, escapou à atenção teórica que a diferença sexual também é efeito tanto do regime sonoro no cinema hegemônico quanto de seu regime visual, e a voz feminina é tão implacavelmente mantida sob representações normativas e funcionalidades quanto o corpo feminino. (SILVERMAN, 1988, p. viii).

Considerando a trilha sonora ao lado da imagem visual, este artigo discutirá como a voz feminina é gravada, manipulada e representada, confirmando, deste modo, as considerações de Silverman de que existiria, de fato, um preconceito sonoro que restringe a voz feminina no cinema.

Além disso, o estudo das vozes em gritos, falas e cantos nos filmes levanta questões mais amplas sobre a gravação da voz no cinema e sugere que, se o regime da aparência na trilha visual coloca a mulher em um papel com objetivo específico, assim também o faz o regime sônico do design sonoro. Isso é especialmente verdadeiro no que diz respeito à maneira tradicional como os cantos das mulheres têm sido gravados. Este artigo investiga como as vozes femininas de fala, canto e grito são geralmente gravadas no cinema americano, através de um exame das práticas de microfone e do uso de reverberação. O que se segue também explorará como a voz feminina é controlada, sendo-lhe permitida ou negada a habilidade para incorporar um espaço, tanto em termos de reprodução técnica quanto de narrativa.

Michael McCallion (1988, p. 100-102) destaca particularidades para as vozes femininas e masculinas e observa que existem dois registros para a voz da fala humana, identificados como o primeiro e o segundo registro. Normalmente a voz feminina é 
contida principalmente no segundo registro ou head voice (voz de cabeça, registro da face ou segundo registro), enquanto que a voz masculina é situada no primeiro registro ou chest voice (registro de peito ou primeiro registro). Existe uma sobreposição entre essas vozes e as notas mais graves da voz feminina estão situadas no primeiro registro. Contudo, o autor observa que a voz feminina geralmente parte do primeiro registro e passa para o segundo, em que se situa sua principal extensão vocal. A mudança do registro de peito para o registro de cabeça ocorre mais frequentemente nas vozes femininas que nas masculinas. A voz feminina do canto, quando não treinada, tende a se situar no registro de peito e busca atingir notas além das capacidades torácicas. A transição entre o primeiro e segundo registro é comumente tranquila e imperceptível; contudo, se houver problemas com a laringe, a mudança de tom será percebida.

Roland Barthes descreve a sensação de ouvir um cantor cuja voz contenha "o grão da voz". Por grão ele está se referindo "ao corpo na voz" (BARTHES, 1977, p. 188). Essa voz é ressoante com os sons "da língua, da glote, dos dentes, das membranas mucosas, do nariz" (SHINGLER, 2006). Raramente a voz feminina inexperiente contém "o grão" e, como forma de compensação, ela pode ser dublada por uma voz profissional ou gravada em aproximação (close up) sem uma percepção de reverberação do espaço no qual está situada. Isso permite uma perspectiva auditiva mais próxima que convida a uma intimidade com o público. Essa falta de reverberação se vê nas vozes femininas mais gravadas na indústria de música pop, o que permite que os ouvintes se sintam irrealisticamente mais próximos à cantora, como se a artista estivesse sussurrando para eles. As vozes masculinas geralmente não são gravadas dessa maneira intimista. Ao contrário, elas são normalmente gravadas com uma distância espacial do microfone, o que permite que suas vozes incorporem um espaço contendo reverberação. A voz masculina é com frequência mais poderosa em termos de profundidade e volume que a voz feminina e lhe é permitido incorporar o espaço mais completamente. Por essa razão, o microfone é frequentemente colocado mais longe da boca masculina e uma sensação maior da voz no espaço (com reverberação) é gravada.

3. Segundo o músico e maestro Jairo Perin, há pontos de ressonância diferentes tanto na voz cantada como na voz falada, conforme a altura em que se está trabalhando. Na literatura brasileira específica, a chest voice corresponderia ao registro de peito ou pequeno registro e exprimiria os sons graves. Já a head voice, voz de cabeça, corresponderia ao registro médio, além de contemplar o terceiro registro (como o falsete ou falsa voz) que usa o registro da face, e exprime os sons agudos, as notas mais elevadas. (N. T.) 
Cantando na Chuva (1952) exemplifica neste artigo uma narrativa central focada na chegada do som e a introdução do processo de dublagem; Cidadão Kane (1941) nos oferece uma aproximação original com o som. Esses filmes foram feitos ou estão situados entre o final da década de 1920 e a primeira metade da década de 1940. As estudiosas do feminismo no cinema identificaram esse período como aquele em que as personagens femininas puderam transgredir seus papéis tradicionais na tela (cf. Kaplan, 1998; Harvey, 2000). As performances de canto nos filmes citados ocorrem predominantemente em clubes noturnos, no teatro e em estúdios de som. Esse artigo coloca em discussão se uma interpretação do regime sonoro oferece ou não novas leituras desses filmes ou se as personagens femininas representavam algo diferentemente durante esse período; considera-se também, em especial, de que maneira as suas vozes puderam ser consideradas transgressoras. A performance da cantora é central para esses dois filmes e para esta pesquisa.

Em seguida, vamos relacionar esses filmes clássicos de Hollywood aos filmes de David Lynch, Veludo Azul (1986) e Cidade dos Sonhos (2001). Lynch é, provavelmente, o mais importante diretor do ponto de vista da consciência sonora trabalhando no cinema hoje, e recebe os créditos pelo design acústico de todos os seus filmes desde A Estrada Perdida (1996). Veludo Azul e Cidade dos Sonhos baseiam-se nesses primeiros registros das mulheres fatais de Hollywood e ambos mostram performances de mulheres cantando que ecoam as narrativas anteriores dos anos 1920 até 1940.

\section{Cantando na CHUVA}

O surgimento do som e seu impacto para as estrelas de cinema da época são centrais para a narrativa de Cantando na Chuva. Esse musical da MGM foi filmado em 1952, mas relata acontecimentos de 1927, depois do lançamento e sucesso de $O$ Cantor de Jazz (1927), da Warner. No contexto de uma história de amor tradicional montada entre o advento das falas, a história dobra-se sobre o conceito de dublagem, ou revoicing ${ }^{4}$. No filme, após o sucesso de um filme sonoro, os chefes do estúdio ficcional Monumental Pictures decidem que eles também precisam produzir um. A atriz principal, Lina Lamont (Jean Hagen), no entanto, não tem uma voz que poderia ser bem transferida para o filme sonoro. Sua voz anasalada e seu sotaque de

4. O revoice ou overdub é uma técnica utilizada nas gravações de áudio que consiste em substituir a voz ou a trilha sonora, gravada anteriormente em outro local, regravando-a em um estúdio. (N. T.) 
classe operária, ainda que este último não seja explicitamente apontado, são considerados inaceitáveis. Cosmo Brown (Donald O'Connor) e Don Lockwood (Gene Kelly) decidem que, a fim de salvar seu mal recebido filme, The Duelling Cavalier [O Cavaleiro Combatente], eles têm que dublar a voz de Lina com uma atriz desconhecida, Kathy Selden (Debbie Reynolds), fazendo de The Duelling Cavalier um musical: The Dancing Cavalier [O Cavaleiro Dançante].

Steve Cohen comenta a dublagem da voz de Lina por Kathy no filme: "[...] enquanto Kathy dubla Lina cantando e falando, a voz de Debbie Reynolds é dublada por outras. Beth Noyes para as músicas e também para maior reflexividade própria, e Jean Hagen - que interpreta Lina - para os diálogos." (COHAN, 2000, p. 59).

Essa dublagem de Kathy pela mulher que, de fato, ela supostamente estaria dublando é uma reviravolta bizarra, que revela a verdadeira construção da natureza do filme e, em particular, da trilha sonora. Talvez, Jean Baudrillard esteja certo quando sugere que " $[\mathrm{o}]$ simulacro nunca é o que oculta a verdade - é a verdade que oculta o que não existe. O simulacro é verdadeiro." (BAUDRILARD, 1991, p. 07). Seria um exercício fútil procurar uma voz "autêntica" no cinema já que as trilhas sonoras são frequentemente feitas por inúmeras tomadas, revoiced ou dubladas.

Peter Wollen refere-se a essa troca de voz ao destacar as origens dos contos de fada desde A Pequena Sereia, de Hans Chrisitan Anderson (WOLLEN, 1992, p. 54). Cantando na chuva tem uma reviravolta distinta em relação a esse conto de fada, posto que Lina não busca tomar a voz de Kathy. Cosmo é quem convence Don e Kathy a encorajar o chefe do estúdio e, finalmente, Lina, de que esse seria o único modo de salvar o filme. É um produto do ouvido patriarcal que, no final das contas, procura controlar ambas as vozes de Lina e Kathy. Nas palavras de Chion: "A voz leva a melhor nessa estranha disputa em que os homens, aqueles que decidem se a cortina mabusiana ${ }^{5}$ deve subir ou descer, atuam como senhores da voz." (CHION, 1999, p. 133). Não é apenas a voz de Kathy que é roubada, mas também a de Lina. Lina constantemente tenta falar por si mesma e essa oportunidade lhe é negada pelas personagens masculinas que a rodeiam. Wollen lembra que:

Tematicamente, é importante que o veiculador da mentira seja a mulher, e não o homem. Em termos ideológicos, em nossa cultura, é a mulher quem é primeiramente

5. Referência a Mabus, o terceiro anticristo previsto nas profecias de Nostradamus. (N. T.) 
Falar, Cantar, Gritar: o controle da voz feminina no cinema americano

colocada para representar a 'natureza' e, portanto, a mentira não natural de uma mulher como Lina, pode ser construída como a mais repreensível. (WOLLEN, 1992, p. 56).

Wollen avança ao apontar como o filme prepara seu bolo ${ }^{6}$ (talvez aquele do qual Kathy pula para fora) e o come. Mais tarde, vemos Don mostrando a Kathy o artifício da beleza no cinema, o uso de luzes, máquinas de vento etc. Wollen conclui: "Aqui a mulher é colocada mais do lado da fantasia do que da natureza, e a fantasia requer artifícios." (WOLLEN, 1992, p. 56). O que é importante notar é que Kathy deve ser convencida da importância da fantasia no cinema com o propósito de que o público encontre uma conformidade aceitável na construção do seu processo de dublagem.

Essa prática de dublagem em filmes acontece desde 1929 e depende das vozes dos próprios atores ou de outros (atores de vozes) para criar as vozes dos personagens. Com a chegada do som ao cinema, muitas atrizes ficaram angustiadas sobre como suas vozes seriam transferidas para o filme. Um sotaque 'inglês' neutro era tido como o mais adequado (GLEDHILL, 2007, p. 205-207). A voz de Lina era considerada inaceitável. Seu sotaque anasalado, de classe operária e regional, tem sido a marca das vozes de personagens femininas em muitos filmes cômicos e tem funcionado para caracterizar a falta de respeitabilidade de uma personagem feminina, tal como Susan Alexander (Dorothy Comingore) em Cidadão Kane.

\section{CIDADÃO KANE}

O som da voz de ópera é reconhecido por sua qualidade vigorosa e reverberante; espera-se uma presença de voz poderosa para envolver todo um auditório. Em representações cinemáticas de óperas, a gravação precisa garantir essas qualidades sônicas para que a voz seja reproduzida de forma verídica. Em Cidadão Kane, no entanto, a narrativa exige que a performance de uma cantora de ópera não alcance esse padrão. $\mathrm{O}$ controle da voz é crucial para a narrativa do filme e, conforme a história avança, vemos que é a inabilidade de Charles Foster Kane (Orson Welles) controlar a voz de Alexander que precipita o fim de seu segundo casamento e leva à sua própria derrocada.

6. Trata-se de um jogo de sentido com o uso do provérbio "you can't have your cake and eat it (too)" que literalmente significa algo como "você não pode ter um bolo e comê-lo ao mesmo tempo", ou seja, não se pode ter ou fazer tudo ao mesmo tempo. (N. T.) 
Quando ouvimos Kane dizer à imprensa "Nós seremos uma grande estrela de ópera”, torna-se claro que, a partir desse ponto do filme, ele está condenado. A esse respeito Chion argumenta:

Este "nós" testemunha sua apropriação amorosa da voz do outro. Mas já que não se pode ser senhor de uma outra voz nem fazê-la um instrumento de seu próprio poder, quando o dono da voz se recusa a obedecer, Kane consegue o que ele estava procurando. Sua reputação é ridicularizada, sua influência reduzida quase a zero. (CHION, 1994, p. 191).

Alexander é uma "cantora” que Kane tenta transformar em estrela; ele a matricula para ter aulas de canto. A qualidade da sua voz de canto, porém, é muito fraca e, durante as cenas das lições musicais, uma certa dose de comédia origina-se da frustração do instrutor com seu fraco desempenho.

A voz dela vai de head voice a chest voice, e o esforço de tentar alcançar as notas além da sua extensão é óbvio. Todavia, o humor na cena dissipa-se assim que fica evidente que é a teimosia e controle de Kane que mantêm Alexander, infeliz e contra a vontade dela, nas aulas de canto. Por fim, ela é forçada a estrear uma ópera no teatro que Kane construiu especialmente para ela, e suas deficiências como diva são cruelmente expostas.

Essa humilhação é visualizada em uma tomada impressionante, a câmera vai sendo erguida até os assistentes de palco, junto às varas de luz no alto do teatro, enquanto a voz de Alexander pode ser ouvida interpretando uma ária no palco abaixo. Em resposta à performance de Alexander, um dos assistentes segura seu próprio nariz. Essa reação é importante, pois reflete o pressuposto de que ele tem experiência em ouvir muitas cantoras de ópera e, portanto, sua avaliação quanto à habilidade de Alexander transmite essa convicção. Sua avaliação honesta rompe com as opiniões pessoais ou políticas que Kane costuma receber e com os comentários dos aduladores que o cercam.

O som na cena em que há a elevação da câmera no teatro de ópera teve que ser criado na pós-produção, já que o cenário de filmagem era um composto de cenários miniatura e foi filmado em tomadas separadas. A voz de Alexander se torna mais distante conforme a câmera se afasta dela. Isso não apenas afeta o volume da voz: a reverberação vinda da acústica do teatro também se torna mais presente na trilha sonora de acordo com a elevação da câmera. Bernard Herrmann, o compositor 
Falar, Cantar, Gritar: o controle da voz feminina no cinema americano

do filme, empregou uma jovem cantora de ópera, Jean Forward, da Ópera de São Francisco, para dublar a voz da personagem. Herrmann explica:

Nosso problema era criar alguma coisa que desse ao público o sentimento de areia movediça, à qual essa garotinha, que tem charme mas uma voz fraca, é subitamente arremessada. E nós tínhamos que fazer isso em termos de cinema, não musicais. Teve de ser feito rapidamente. Tínhamos que ter o som de uma enorme orquestra golpeando-a, enquanto todos gritavam para ela - 'Agora, vá, ande!' - e a jogavam em uma areia movediça. Não existe ópera que comece desse modo. Nós tivemos que criar uma. Eu, pessoalmente, não pretendia escrever uma sequência de ópera como essa, mas KANE exigia isto. Não o Welles, mas KANE. Esse era o único modo, do ponto de vista do cinema, de expressar o horror no qual aquela garota estava. Encontramos uma cantora muito charmosa para dublar a voz de Susan, explicando a ela o propósito desse efeito. E vejam: a razão pela qual Susan está com tantas dificuldades não é porque ela não pode cantar, mas porque a exigência da sua linha de canto é propositadamente maior do que ela jamais encontrou. (HERRMANN, 1980, p. 127-128, destaque no original).

A cantora de ópera que Herrmann contratou tinha uma boa voz mas sua extensão não atingia as notas mais agudas. Jean Forward foi uma escolha importante para Herrmann e Welles já que a voz de ópera precisava quase ser bem sucedida. Alexander quase parece ser boa o suficiente para ser uma cantora de ópera e Kane quase tem êxito. A atenção para o detalhe na trilha sonora permite a Welles, Herrmann e ao departamento de som (liderado por James G. Stewart e Bailey Fesler) criar um filme ousado que representa sonoramente vários ambientes reais.

Outro exemplo do controle de Kane sobre a voz de Alexander acontece quando eles vão a um piquenique. Ele brigam dentro de sua tenda e, fora, ouvem-se música e cantoria. Kane tenta fazer com que Alexander se cale, buscando (não pela primeira vez) controlar sua voz. Quando ela se recusa, ele a esbofeteia, e não se desculpa. Ouve-se, na trilha sonora, um grito de uma outra mulher do lado de fora. Metaforicamente, o grito denota a voz de Alexander, silenciada pelas ações dele. Kane a tem controlado de tal forma que as reações naturais dela são impedidas pelo comportamento opressivo dele.

Em casa, enquanto discute com Kane, a voz de Alexander muda, seu sotaque é alterado e seu tom fica mais agudo. Sua pronúncia fica mais regional e próxima da classe operária: ela não está atuando para ele. No piquenique, e em uma cena 
posterior em que Alexander discute com Kane sobre a crítica do Leland, Alexander libera seu sotaque, reconquistando o controle sobre sua própria voz.

Por fim, quando Alexander deixa Kane, nós ouvimos o grito de um pássaro. Esse som simboliza que Alexander escapou da gaiola de Kane e não mais representa o pássaro preso. Kane estava obcecado na tentativa de controlar o mundo ao seu redor. No início, essa tentativa era através das palavras escritas no jornais, depois através da política e, por fim, através da voz de Alexander. Silverman observa a cilada de Alexander:

Kane não apenas acumula as riquezas do mundo em uma vã tentativa de compensar as divisões e separações sobre as quais sua subjetividade está baseada, mas constrói um teatro de ópera para prender uma voz cuja sonoridade envolvente ele, por sua vez, espera guardar para, enfim, reencontrar sua falecida mãe. (SILVERMAN, 1998, p. 86).

Alexander, ao finalmente conseguir escapar do controle de Kane, constrói para si uma carreira menos proeminente como cantora, de modo similar ao de Gilda (Rita Hayward) no clube Latin America no filme Gilda7.

Cidadão Kane é um desvio radical das práticas dominantes do cinema, tanto em termos de técnica como de narrativa. Permite-se que a voz de canto feminina incorpore o espaço, mas através dessa incorporação a voz falha em preencher o teatro. Kane busca controlar a voz de Alexander ao mantê-la nas lições de canto, construindo-lhe um teatro de ópera, batendo nela e transformando sua mansão em uma armadilha. Todavia, como diretor, Welles expõe as imperfeições de Kane como indivíduo. Embora o protagonista busque controlar Alexander, por fim ele é condenado e o filme termina em tragédia. Alexander foi controlada e tem sua voz levada ao limite por Kane, e essa também é uma questão narrativa e técnica em Veludo Azul.

\section{VELUdo AZUL}

Em Veludo Azul, Dorothy (Isabella Rossellini) grita quando descobre Jeffrey (Kyle McLaughlin) em seu guarda-roupa. Mais para o final do filme ela grita outra vez e, então, desmorona na frente de Jeffrey e Sandy (Laura Dern). Ann Kroeberr, a produtora de gravação de áudio, empregou uma técnica interessante para aumentar o impacto emocional dessas cenas. Manipulou bastante a gravação da voz de

7. Cf. Greene (2007) para maiores informações sobre a voz feminina de cantoras em Gilda. 
Dorothy. Em um Nagra (um gravador de fita analógico), ela acionou o mecanismo de ganho do aparelho sutilmente em uma cena na qual a voz de Dorothy vai do sussurro ao grito. Quando Dorothy começa a gritar com Jeffrey, Kroeber amplia esse ganho até que a voz de Dorothy ficasse levemente distorcida, e isso fez com que sua voz parecesse ainda mais intensa. $O$ que se ouve na trilha sonora é a voz dela se partindo, literalmente, como se tivesse alcançado um registro superior e isso representa, psicologicamente, seu colapso mental (KROEBER, 2006).

Kroeber gravou todas as cenas histéricas de Dorothy desse modo. Contudo, essa técnica é apenas possível com o uso de um gravador analógico, que é mais flexível para a distorção do que o digital. A captura do som da fala no local de gravação precisa ser a mais mais limpa possível; existe muito pouca margem para experimentação no estúdio de filmagem. O risco que Kroeber assumiu foi considerável em termos de possíveis custos de pós-produção ADR (Automated Dialogue Replacement ${ }^{8}$ ), caso ela tivesse falhado. Mas sua técnica funcionou brilhantemente. A manipulação da voz acrescentou uma camada emocional à cena que, mesmo não percebida conscientemente pelo público, sem dúvida era registrada e entendida subconscientemente. A produção de som de Kroeber impactou a gravação e a representação da voz.

Há outra manipulação da produção de som nas cenas em que Dorothy canta. $\mathrm{Na}$ verdade, tudo o que Dorothy canta em Veludo azul é dublagem; a voz é montada a partir de diferentes tomadas. A própria Rosselini admitiu que não era cantora e que, na verdade, tinha uma voz muito ruim (ROSSELLINI, 2002). Não possuindo uma voz treinada, ela teve dificuldades para executar o que estava previsto para cantar. O compositor Angelo Badalamenti construiu a música a partir de várias tomadas cantadas por Rossellini e o produto final foi, então, reproduzido no set durante a gravação do filme.

A gravação da voz de Dorothy no microfone é próxima e intimista, sem a reverberação que poderia ser esperada de uma performance ao vivo. Nas cenas do Slow Club, Frank (Dennis Hopper) pode ser visto ouvindo Dorothy cantar, enquanto ele alisa um tecido de veludo azul. Seus olhos estão fechados em algumas dessas cenas de performance e a voz do microfone junto à boca de Dorothy, assim como o tecido que acaricia, torna-se um objeto de fetiche para ele. Ao escrever sobre o filme de King Vidor Stella Dallas (Mãe Redentora, 1937) Linda Willians chama atenção para aquilo que ela denomina de "[a]montoados de estilos, camadas de maquilagem, roupas e joias - esses

8. Substituição Automática de Conversas. (N. T.) 
são, certamente, acessórios da mulher fetiche" (WILLIAMS, 1987, p. 331). O mesmo nível de fetichização fica óbvio no 'amontoado de acessórios' que adornam Dorothy em Veludo Azul. Seu traje de palco compõe-se de um vestido de veludo azul, uma enorme peruca cacheada e muita maquilagem, especialmente uma sombra de olhos azul e um batom brilhante vermelho. Para Barbara Creed, a aparência de Dorothy, com os lábios excessivamente pintados de vermelho, incorpora a representação de uma 'vagina com dentes', a mulher castrada (CREED, 1993, p. 106-107). Tal é o nível de acessórios estilizados que Dorothy pode quase ser considerada o "doce palhaço colorido" de Roy Orbison, da música "In Dreams”, dublada mais tarde por Ben (Dean Stockwell). Aletra dessa canção traz o verso "Eu fecho os olhos e vago por aí" e isso ecoa no modo como Frank ouve a performance de Dorothy no Slow Club. Seus olhos estão fechados; ele não olha para a mulher fetichizada à sua frente; ao invés disso, ouve sua voz.

A escuta atenta de Frank sugere uma intimidade artificial com a performance de Dorothy. Na realidade, podemos argumentar que, através da gravação próxima ao microfone da voz de Dorothy e da falta de reverberação, cria-se uma escuta que equivale ao conceito de olhar masculino de Laura Mulvey (MULVEY, 1986); esse olhar privilegia o ouvido masculino e, portanto, a voz feminina é objetivada. Elizabeth Weis (1999), em Eavesdropping: an aural analogue of voyeurism ${ }^{9}$, destaca o papel da escuta atrás da porta no cinema:

Os filmes que tratam da escuta atrás da porta levantam questões que têm a ver com a própria natureza do meio. Por um lado, em um primeiro plano, isso tem a ver com o voyeurismo, o modo como o cinema parece invadir a privacidade - a maneira como personagens em todos os filmes de drama parecem ser espionados e ouvidos secretamente. Como no voyeurismo, espiar atrás da porta pode questionar de modo reflexivo nossa relação de privacidade para com o filme, nosso amor em escutá-lo, nossa cumplicidade com quem se esconde para ouvir... Escutar atrás da porta é, inerentemente, uma ação do cinema; [...] a situação requer ao mesmo tempo informação visual e de áudio, e assim, talvez, só possa ser bem explorada em filmes. (WEIS, 1999, n. p.).

Espiar atrás da porta é um ponto chave no cinema de Lynch e a performance de Dorothy no Slow Club é filmada e gravada para destacar a posição de ouvinte de Frank. Além disso, o sotaque europeu de Rossellini é muito forte em sua interpretação,

9. "Escuta atrás da porta: uma escuta análoga do voyeurismo" (sem tradução encontrada em português). (N. T.) 
aumentando sua alteridade exótica para um público norte-americano (aqui simbolizado pela escuta concentrada de Frank). Em outras palavras, o sentido da mulher como fetiche masculino é alcançado tanto através de uma cuidadosa produção sonora quanto visual. O sotaque de Rossellini também acrescenta "o grão da voz" nessas performances. A estrangeiridade exótica da mulher cantora retorna em Cidade dos Sonhos.

\section{CIDADE DOS SONHOS}

No filme Cidade dos Sonhos (LYNCH, 2001), encontramos uma aventura a mais no uso do som, que se destaca pelo uso criativo da performance vocal feminina. Trata-se de uma obra especialmente interessante para ilustrar como a voz é concebida e, depois, gravada. A reverberação presente na voz contrasta significativamente com as normas de gravação da voz feminina em filmes e músicas.

Na prática convencional, tanto na indústria musical como na fílmica, o processo de gravação do canto feminino ocorre de maneira similar. A opinião do público é considerada fundamental e uma boa recepção da voz é algo crítico para as técnicas de gravação. Mulvey afirma: "A voz existe no limiar da ressonância e do significado. De um lado, fornece uma textura material para a trilha sonora geral de um filme; por outro, expressa uma mensagem específica através da linguagem, no discurso." (MULVEY, 2003, p. 15). Embora tenha escrito sobre o início do cinema falado, a análise de Mulvey diz respeito também ao cinema contemporâneo, e ilustra a natureza ressonante e significante tanto da voz falada como da cantada.

Em Cidade dos Sonhos, o Clube Silêncio consagra-se como um espaço em que os cantores dublam pré-gravações; suas apresentações brincam com as percepções de um evento que acontece ao vivo. O MC Bondar (Richard Green) age como um mágico sonoro conjurando o real, o gravado e o representado. Rebekah Del Rio (dublando a si mesma) interpreta a canção "Llorando" a cappella ${ }^{10}$, uma versão espanhola da música "Crying" (Roy Orbison). Essa abordagem assíncrona difere da escuta habitual e das qualidades visuais do cinema hollywoodiano. $\mathrm{O}$ canto de Del Rio é primeiramente ouvido de maneira sincrônica, mas a continuação da canção, depois que ela desmaia, é apresentada para romper com a narrativa linear tão fundamental ao cinema de Hollywood.

Lynch descreve a gravação da voz de Del Rio:

10. A cappella quer dizer sem acompanhamento instrumental. (N. T.) 
Uma manhã o agente musical Brian Loucks trouxe Rebekah Del Rio ao meu estúdio, e o Brian, de vez em quando, vinha me apresentar algum cantor, algum músico. Então a Rebekah veio apenas para tomarmos um café e, de repente, ela decidiu ficar em pé na minha frente e cantar alguma coisa. Naquele tempo, John Neff trabalhava ali como engenheiro de som e eu pedi que ele ligasse o microfone de uma pequena cabine. Depois que Rebekah entrou lá, nós desistimos daquele café. Ela simplesmente entrou na cabine e o que ela cantou ali dentro, com aquele microfone, foi o que entrou no filme, cinco minutos. Depois, acrescentou-se uma reverberação para a sala, apenas isso. Sua sincronização labial é impecável pois é ela, ela é quem canta desse modo. (LYNCH, 2007, n. p.).

No filme, não há dúvidas de que, quando a mulher canta, um público diegético e não-diegético ${ }^{11}$ sabe que se trata de uma gravação, mas quando ela, repentinamente, desmaia, o horror desse playback assíncrono é profundamente chocante. Lynch é capaz de criar essa armadilha devido ao seu entendimento sobre a natureza do som. Ele usa a voz reverberante de Rebekah Del Rio para dar a ilusão de que existe um evento sonoro ao vivo acontecendo. Essa disjunção entre o que soa ao vivo e o que, na realidade, foi gravado, levanta questões a respeito das convenções de gravação sonora no teatro e no cinema.

O efeito é possível porque a gravação da voz de Del Rio difere bastante das formas padronizadas. Como Del Rio dubla a si mesmo durante "Llorando", o som da voz e sua forte impostação vocal aparecem em um espaço vivo; a reverberação do teatro está presente. Isso é significativamente diferente da qualidade de som habitual do canto feminino no cinema, como já se evidenciou nos outros filme aqui apresentados. Não existe apenas uma intimidade mas, também, uma força da performance. A imagem em close up de Del Rio tem uma intensidade poderosa quando associada com a reverberação de sua voz.

Aqui, a qualidade da voz de canto é crucial, "o grão da voz” apresenta-se na performance de Del Rio. Sua forte voz em segundo registro, tomada em uma primeira

11. Diegético e não-diegético referem-se, frequentemente, à relação entre a imagem e o som na construção ficcional do filme. Resumidamente, diegético é quando temos a percepção de que o som ou a música faz parte da ação das personagens de um filme, como, por exemplo, uma personagem de fato ouve uma música e nós a vemos fazer isso, ao mesmo tempo em que, também, escutamos a música. Não-diegético é quando não temos uma associação de correspondência direta entre as ações da personagem que visualizamos e o som que ouvimos, por exemplo, vemos as ações da personagem e ouvimos uma música de fundo que não é sincrônica a essas ações nem está presente na cena ou faz parte dela. (N. T.) 
gravação da música, preenche poderosamente o auditório. A cena no Clube Silêncio acontece logo após a relação sexual entre Betty/Diane (Naomi Watts) e Rita/ Camila. Elas entram no clube e ouvem Del Rio cantar. O que é interessante sobre a escolha dessa música é que, além da versão original ser de Orbison, sua versão mais famosa foi gravada por uma cantora lésbica k. d. lang. Sua interpretação hispânica faz o público lembrar da primeira versão e acrescenta uma outra sobreposição à associação lésbica que a canção já adquiriu. Através dessa sutil escolha musical, Lynch consegue apontar o que ocorreu com as duas mulheres como uma relação lésbica. Isso é interessante em termos de um público diagético que inclui Betty/ Diane e Rita/Camila. O público não é apenas homogêneo e masculino, mas inclui mulheres e, de forma explícita, as lésbicas. Cidade dos Sonhos pode ser considerado, em termos acústicos, como uma obra que apresenta uma abordagem feminista através da trilha sonora, tanto na forma como no conteúdo. Embora a apresentação de Del Rio seja uma mímica, trata-se de uma atuação dramaticamente emotiva.

De várias maneiras, a performance de gênero de Del Rio é liberadora em relação a outras presentes no cinema de Hollywood. Ela é similar à personagem de Ben em Veludo Azul, ambas são fantoches de ventríloquos. Lynch é o ventríloquo ou o senhor das marionetes, é quem controla as cordas. Contudo, o desmaio de Del Rio no palco durante a música e a performance também se assemelham visualmente ao colapso de Dorothy no final de Veludo Azul.

Dorothy rui no final do filme, apenas para ser salva por Jeffrey. Ela não consegue salvar seu marido ou recuperar seu filho pelos seus próprios méritos. $\mathrm{O}$ colapso de Dorothy é tanto físico quanto mental; não fica claro se ela será capaz de juntar as peças novamente. Na verdade, a soma da performance e do colapso de Del Rio, embora espelhe momentos anteriores de Veludo Azul, tem uma ressonância muito mais profunda em Cidade dos Sonhos. Os elementos alcançaram uma totalidade maior, criaram um filme mais desafiador, questionador e emocionalmente mais satisfatório. A representação de personagens femininas se desenvolveram para além da representação da diva clássica ou da femme fatale de Veludo Azul. Nos termos de Chion:

Nunca Lynch chegou tão perto desse tema, através de duas mulheres que se encontram e mesclam suas aventuras, como se Sandy e Dorothy de Veludo Azul tivessem decidido experimentar uma história juntas, colocando o homem ou os homens de lado; a ponte masculina foi removida. Adão não é mais o articulador entre as mulheres de dois mundos opostos, como Jeffrey era em Veludo Azul, e as mulheres passam 
de uma identidade de risco a outra enquanto a realidade se desintegra ao redor delas. (CHION, 2006, p. 221).

Em Cidade dos Sonhos temos um melhor entendimento sobre as personagens femininas e, embora não tenhamos a história de Del Rio, sua trágica apresentação espelha, tanto para Betty/Diane como para Rita/Camilla, as complexidades do amor e da vida de uma atriz e performer em Hollywood.

Veludo Azul e Cidade dos Sonhos diferem quanto a técnicas e abordagens de gravação e quanto ao papel da voz feminina. Cidade dos Sonhos subverte a narrativa cinematográfica ao explorar o artifício de gravação da voz. A atuação de Del Rio chama a atenção para a natureza real, representada e gravada da performance tanto para a música como para o cinema. Sua performance também consegue ser emocionalmente satisfatória, ainda que a ilusão da situação fique bastante clara para o público.

\section{Conclusão}

Todos os filmes aqui discutidos têm performances vocais fundamentais realizadas por personagens femininas. Em termos de narrativa, suas vozes - ao falarem, cantarem e gritarem - são essenciais para serem reconhecidas enquanto personagens. Isso levou a algumas inovações técnicas. Cidade dos Sonhos busca tecer a narrativa e a técnica em conjunto para saturar o filme com uma profunda ressonância, e o desenvolvimento das práticas de gravação no filme impulsiona ainda mais a narrativa e o impacto emocional da performance.

O cinema é um meio que utiliza tanto o som quanto a imagem, mas, tradicionalmente, os estudos fílmicos acadêmicos têm ignorado bastante o elemento sonoro. Assim como apontado por Silverman (1988), o som e o design sonoro no cinema não vinham recebendo consideração crítica nos estudos fílmicos e essa falha pode deturpar seriamente os sentidos e as ideologias de uma obra. Entretanto, o som, especialmente a gravação da voz, é tão importante quanto o visual para atribuir sentido ao filme; e as convenções para a gravação dos sons, assim como as convenções para câmera e enquadramento, constroem e conferem certas posições ao sujeito. A maneira como se grava uma voz e como lhe são atribuídas certas características espaciais e de reverberação na sua reprodução sonora pode permitir à personagem incorporar uma posição mais completa no espaço. Em geral, essa incorporação tem sido negada às personagens femininas, e é apenas com uma abordagem radical da 
Falar, Cantar, Gritar: o controle da voz feminina no cinema americano

trilha sonora, criada por diretores com consciência sonora, designers, gravadores e operadores de som, que esse desequilíbrio poderá ser enfrentado.

\section{REFERÊNCIAS ${ }^{12}$}

BARTHES, R. Image, Music, Text. Trans. Stephen Heath. London: Fontana Press, 1977.

BAUDRILARD, J. Simulacros e simulação. Tradução de Maria João da Costa Pereira. Lisboa: Relógio D'Água, 1991.

CHION, M. Audio-Vision: Sound on Screen. Trans. Claudia Gorbman. New York: Columbia University Press, 1994.

. The voice in cinema. Trans. Claudia Gorbman. New York: Columbia University Press, 1999. . David Lynch. Trans. Robert Julian. $2^{\text {nd }}$ edition. London: BPI Publishing, 2006.

COHAN, S. Case Study: interpreting Singin' in the rain. In: GLEDHILL, C.; WILLIAMS, L. (Ed.). Reinventing Film Studies. London: Arnold Publishers, 2000.

CREED, B. The Medusa's Head: The Vagina Dentata. In: . The Monstrous Feminine: Film, Feminism, Psyclloanalysis. London \& New York: Routledge, 1993.

GLEDHILL, C. The Screen Actress Prom Silence to Sound. In: GALE, M. B.; STOKES, J. (Ed.). The Cambridge Companion to the Actress. Cambridge: Cambridge University Press, 2007.

GREENE, L. The Woman Sings: Sound Design and Meaning in Hollywood Cinema. In: MCLOONE, M.; ROCKET, K. (Ed.). Irish Films, Global Cinema: Studies in Irish Film 4. Dublin: Four Courts Press, 2007.

HARVEY, S. Woman's Place: The Absent Family of Film Noir. In: KAPLAN, E. A. (Ed.). Women in Film Noir. London: BFI, 2000.

HERRMANN, B. Bernard Herrmann, Composer. In: CAMERON, E. W. (ed.). Sound and the Cinema: The Coming of Sound to American Film. New York: Redgrave Publishing Company, 1980.

KAPLAN, E. A. Women in Film Noir. $2^{\text {nd }}$ edition, London: British Film Institute, 1998.

KROEBER, A. Entrevista. Berkeley, California, USA, 3 August, 2006.

LYNCH, D. Entrevista. Belfast, 22 October, 2007.

MCCALLION, M. The Voice Book. London: Faber \& Faber, 1988.

MULVEY, L. Visual Pleasure and Narrative Cinema. Reprinted. In: ROSEN, P. (Ed.). Narrative, Apparatus, Ideology: a film reader. New York: Columbia University Press, 1986.

. Cinema, Sync Sound and Europe 1929: Reflections on Coincidence. In: SIDER, L.; FREEMAN, D.; SIDER, J. (Ed.). Soundscape: the School of Sound Lectures 1998-2001. London \& New York: Wallflower Press, 2003.

SHINGLER, M. Fasten Your Seatbelts and Prick Up Your Ears: The Dramatic Human Voice in Film. Scope: an online journal of Film and TV Studies (Sound Special Issue), Issue 5: June, 2006. Disponível em: <https://www.nottingham.ac.uk/scope/documents/2006/june-2006/shingler. pdf $>$. Acesso em: 08 out. 2007.

12. A versão original em inglês traz obras não citadas no corpo do texto. Para a tradução, seguimos as normas editoriais desta revista e listamos apenas as obras de fato citadas, algumas em português. (N. T.) 
SILVERMAN, K. The Acoustic Mirror: The Female Voice in Psychoanalysis and Cinema. Bloomington \& Indianapolis: Indiana University Press, 1988.

ROSSELINI, I. Entrevista. In: MYSTERIES OF LOVE. Direção: Jeffrey Schwarz. Los Angeles, 2002. Edição especial. DVD.

WEIS, E. Eavesdropping: An Aural Analogue of Voyeurism. In: BROPHY, P. (Ed.). Cinesonic: The World of Sound in Film. North Ryde: Australian Film Television \& Radio School, 1999. Disponível em: <https://web.archive.org/web/20120116232454/http://lavender.fortunecity. com/hawkslane/575/eavesdropping.htm>. Acesso em: 24 out, 2007.

WILLIAMS, L. Something else beside a mother: Stella Dallas and the Maternal Melodrama. In: GLEDHILL, C. (Ed.). Home is Where the Heart is: Studies in Melodrama and the Woman's Film. London: BFI, 1987.

WOLLEN, P. Singin' in the Rain. London: British Film Institute, 1992.

\section{Filmes estudados}

CIDADÃO KANE. Direção: Orson Welles. EUA, 1941, 1h59min, drama, color. 1 DVD.

CIDADE DOS SONHOS. Direção: David Lynch. EUA, França, 2002, 2h25min, drama, color. 1 DVD.

DANÇANDO NA CHUVA. Direção: Stanley Donen, Gene Kelly. EUA, 1952, 1h42min, comédia musical, color. 1 DVD.

VELUDO AZUL. Direção: David Lynch. EUA, 1987, 2h, suspense, color. 1 DVD.

\section{SOBRE A AUTORA}

Liz Greene é graduada em Design de Som (Institute of Art, Design and Technology, Dun Laoghaire, Irlanda), com Mestrado em Estudos Fílmicos (University College of Dublin, Irlanda) e Doutorado em Estudos Fílmicos (University of Ulster, Irlanda do Norte). É professora e pesquisadora na Universidade de John Moores (Liverpool, Inglaterra), na Faculdade de Profissionais de Arte e de Estudos Sociais. Pesquisa e trabalha com teoria, história e prática de efeitos do som, incluindo a voz e outros elementos sonoros. Tem experiência na área de edição e captação de som para filmes e documentários.

E-mail: L.Greene@ljmu.ac.uk.

Recebido em 17 de fevereiro de 2017 e aprovado em os de junho de 2017. 